\title{
Impact of Backyard Poultry Rearing on Living Standard of Tribal Community in Kandhamal District of Odisha, India
}

\author{
D.V. Singh ${ }^{1^{*}}$, Anupam Mishra ${ }^{2}$, S.R.K. Singh ${ }^{3}$ and Tushar Athare ${ }^{3}$ \\ ${ }^{1}$ Krishi Vigyan Kendra, Kandhamal, OUAT, Bhubaneswar, India \\ ${ }^{2}$ ICAR- ATARI, Zone-IX, Jabalpur, India \\ ${ }^{3}$ (Agricultural Extension), ICAR- ATARI, Zone-IX, Jabalpur, India \\ *Corresponding author
}

\section{A B S T R A C T}

\begin{tabular}{|l|}
\hline Key w o r d s \\
Backyard poultry \\
farming, Extra \\
income, Living \\
standard, Tribal \\
farmers.
\end{tabular}

Backyard poultry rearing requires minimum input cost, making it highly affordable by the poor village farmers and its high return on investment is known to improve the farmers' living standards. In the present study poultry birds of Banaraja breed were distributed amongst 500 tribal farmers belonging to 5 villages in K. Nuagaon and G. Udayagiri block of Kandhamal district, Odisha. Data were collected using questionnaires. The study revealed that after the technical intervention none of the 39 farmers who belonged to the lower income slab of less than Rs. 8000/ year remained in that group. Over and above, the higher income slab of more than Rs. 15000/year to which only 9 farmers belonged prior to the technical intervention now consisted of 135 farmers. Data relating to the usage of the extra income to improve living standards revealed that the farmers gave priority to essential amenities like electricity $(23.48 \%)$, latrine $(15.65 \%)$, bathroom $(23.48 \%)$ and also $12.66 \%$ of farmers converted their Kaccha houses to Pakka houses. Farmers also purchased luxury items like mobile $(26.96 \%)$ and DVD player $(0.87 \%)$. Therefore, it is concluded that backyard poultry production can be taken up by poor farmers as an extra income generating activity, to improve their living standards.

\section{Introduction}

India ranks $3^{\text {rd }}$ and $6^{\text {th }}$ in the world in poultry egg and meat production, respectively (FAO, 2014). Also $30 \%$ of poultry production is in the unorganized sector. Seventy percent of the world's rural poor depend on livestock as a component of their livelihoods (LID, 1999; FAO, 2002), and a vast majority of those keep poultry (Sonaiya et al., 1999; Epprecht et al., 2007). Village poultry production, known as backyard extensive poultry production, is a common phenomenon in many developing countries. This mode of poultry production is characterized by ownership of up to one hundred birds; generally reared free-range, with minimum or low inputs and zero to minimal bio- security (Guèye, 2000). In fact among the rural poor, poultry is found to be a crucial livelihoods asset for the poorest segments, such as those households that are in the first income quintile (Maltsouglou and Rapsomanikis, 2005; Roland-Holst et al., 2007).

Poultry production by rural poor households contributes to several livelihoods indicators, including (but not limited to) income, 
nutrition, food security, savings, insurance and gender equality (Alabi et al., 2006; Guèye, 2007; Sonaiya, 2007; Smucker and Wisner, 2008). Furthermore poultry production constitutes a quick and high return investment opportunity (Epprecht et al., 2007; Sonaiya, 2007) for improving any one or all of these livelihoods indicators. Moreover, poultry production is often recognized as an entry point into livestock production (Alabi et al., 2006; Guèye, 2007), which is associated with breaking out of poverty traps.

The roles of poultry in income and food security are straightforward to characterize: rural poor households generate cash income through the sales of those poultry and poultry products (Islam et al., 2014) which they do not consume themselves. In rural areas where credit markets are missing, similarly to other large livestock, poultry functions as 'insurance' to hedge against shocks and stresses (Rosenzweig and Wolpin, 1993). Often poultry functions as a 'savings account', which can be tapped into fairly quickly to meet household needs such as school fees, costs of weddings and funerals (Obi et al., 2008). Poultry also contributes to household nutrition, as many rural poor households rely on their own poultry production to supply the majority of their animal source food. Poultry provides not only protein but also highly-bio-available essential micronutrients, such as iron, vitamin $\mathrm{A}$ and zinc, which are crucial especially for child nutrition and health (Iannotti et al., 2008). Chronic malnutrition and micronutrient deficiencies are very high in developing countries (Quinn et al., 1990; Callens and Phiri, 1998) and hence poultry is particularly important for the improvement of this livelihoods indicator.

In fact National Agricultural Innovations Project lists poultry as one of the new income earning activities in which women are increasingly being involved. Household level studies conducted in Africa revealed that women earned significant incomes from poultry sales, even after accounting for household consumption (Chitukuro and Foster, 1997; Alabi et al., 2006).

The objectives of the study were to find out the contribution of poultry farming on rural livelihoods economically, as well as socially and culturally and to small house hold food security. Another look of the study was direct contribution to family reproduction, in the form of meat and eggs, and at its indirect contribution, i.e. when poultry are sold or traded and when birds play a role in maintaining social networks and rural life.

\section{Materials and Methods}

The Tribal Sub Plan has been running since year 2013 at Krishi Vigyan Kendra, Kandhamal, Orissa University of Agriculture \& Technology, Bhubaneswar. Under the TSP, poultry birds of Banaraja breed were provided to 500 tribal farmers belonging to five villages, Banduguda, Katadaganda, Kelamaha, Gambuli and Sudipada of K. Nuagaon and G. Udayagiri block of Kandhamal district to uplift the rural livelihood. Total 30 beneficiaries were randomly selected from each village, thus making a total sample of 150 respondents. The data were collected through questionnaire in right of the data were analyzed. The collected data were analyzed and categorized into different variables.

\section{Results and Discussion}

The data depicted in Table 1 shows that maximum number of poultry farmers $(64 \%)$ belonged to the middle age group of 31-50 years and the remaining $36 \%$ fell in the category of above 50 years. Table 1 shows that based on level of education, the highest 
number of beneficiaries (55.33\%) were found to be illiterate, while 22.67 per cent and 18.67 per cent were educated up to primary and secondary education, respectively. Remaining 3.33 per cent were educated up to secondary education. These results are conformity to Biroll et al., (2010) that households with less educated heads are significantly more likely to keep poultry.

The farmers were grouped according to their occupation, both during the survey and after technology interventions. At the time of base line survey it was observed that the occupation of 79 farmers was farming (Table 1). After three years of technological intervention it was determined that the number of farmers who also took up labour work was gradually reduced from $18.26 \%$ to $2.61 \%$. The data depicted in Table 2 shows that maximum number $(76 \%)$ of beneficiaries lived in Kachha houses. After technology intervention 17 number $(11.33 \%)$ of Kachha houses were converted into Pakka houses.
The electricity and mobile facility were increased due to poultry farming (Table 2). The data depicted in Table 2 shows that $76 \%$ and $44.67 \%$ farmers obtained and used electricity and mobile, respectively after technological intervention.

Prior to these technology none of the beneficiaries owned or used basic amenities like latrine and bathroom, but after the said intervention $21.33 \%$ and $26 \%$ farmers owned latrine and bathroom, respectively.

The vehicle facilities were increased due to poultry farming and data depicted in Table 2 shows that the number of bicycles were increased from 41 to 54 (8.67\% increase) whereas the number of household having bike facility was increased from 17 to $21(2.67 \%$ increase). These results are agreement to Holst et al., (2007) that $50 \%$ of the rural farmers say that more income from livestock including poultry is the reason for their improved living standards.

Table.1 Profile of poultry faming farmers

\begin{tabular}{|c|c|c|c|}
\hline Parameter & Parameter & Number & Percent \\
\hline \multirow[t]{5}{*}{ Age group } & \multicolumn{3}{|c|}{ Distribution of poultry farmers according to age } \\
\hline & Young age (Up to 30 year) & 0 & 0.00 \\
\hline & Middle age (31 to 50 year) & 96 & 64.0 \\
\hline & Old age (Above 50 year) & 54 & 36.0 \\
\hline & Total & 150 & $\mathbf{1 0 0 . 0 0}$ \\
\hline \multirow{6}{*}{$\begin{array}{l}\text { Level of } \\
\text { education }\end{array}$} & \multicolumn{3}{|c|}{ Distribution of poultry farmers according to their level of education } \\
\hline & Illiterate & 83 & 55.33 \\
\hline & Primary education (Up to VII Std.) & 34 & 22.67 \\
\hline & Secondary education (VIII to X Std.) & 28 & 18.67 \\
\hline & Above secondary education & 5 & 3.33 \\
\hline & Total & 150 & $\mathbf{1 0 0 . 0 0}$ \\
\hline \multirow[t]{6}{*}{ Occupation } & \multicolumn{3}{|c|}{ Distribution of poultry farmers according to their occupation } \\
\hline & Farming Only & 79 & 52.67 \\
\hline & Farming + Animal Husbandry & 26 & 17.33 \\
\hline & Farming + Labour work & 27 & 18.00 \\
\hline & $\begin{array}{l}\text { Farming + Animal Husbandry + Labour } \\
\text { work }\end{array}$ & 18 & 12.00 \\
\hline & Total & 150 & 100.00 \\
\hline
\end{tabular}


Table.2 Impact of poultry farming on change in living standard

\begin{tabular}{|c|c|c|c|}
\hline Parameter & Parameter & Before & After \\
\hline Types of & Kachcha & 133 & 114 \\
\hline \multirow[t]{2}{*}{ houses } & Pakka & 17 & 36 \\
\hline & Total & 150 & 150 \\
\hline \multirow{6}{*}{$\begin{array}{l}\text { Facility in } \\
\text { houses }\end{array}$} & \multicolumn{3}{|c|}{ Impact of poultry farming on changes in their facility in houses } \\
\hline & Electricity & 87 & 114 \\
\hline & Latrine & 0 & 32 \\
\hline & Bathroom & 0 & 39 \\
\hline & Mobile & 21 & 67 \\
\hline & Total & 108 & 239 \\
\hline \multirow{4}{*}{$\begin{array}{l}\text { Information of } \\
\text { vehicle }\end{array}$} & \multicolumn{3}{|c|}{ Impact of poultry farming on changes in their holding of vehicle } \\
\hline & Bicycle & 41 & 54 \\
\hline & Bike & 17 & 21 \\
\hline & Total & 46 & 69 \\
\hline \multirow{6}{*}{$\begin{array}{l}\text { Instruments } \\
\text { for } \\
\text { Entertainment }\end{array}$} & \multicolumn{3}{|c|}{$\begin{array}{l}\text { Impact of poultry farming on changes in their holding of Instruments } \\
\text { for Entertainment }\end{array}$} \\
\hline & Radio & 37 & 60 \\
\hline & TV & 9 & 18 \\
\hline & CD player & 2 & 5 \\
\hline & DVD player & 0 & 1 \\
\hline & Total & 48 & 84 \\
\hline \multirow[t]{5}{*}{ Annual Income } & \multicolumn{3}{|c|}{$\begin{array}{l}\text { Impact of poultry farming on changes in their holding of Instruments } \\
\text { for Entertainment }\end{array}$} \\
\hline & Low (up to Rs. 8,000 ) & 39 & 0 \\
\hline & Medium (Rs. 8,000 to 15,000$)$ & 102 & 15 \\
\hline & High (Above Rs. 15,000) & 9 & 135 \\
\hline & Total & 150 & 150 \\
\hline \multirow{4}{*}{$\begin{array}{l}\text { Type of } \\
\text { family }\end{array}$} & \multicolumn{3}{|c|}{ Impact of poultry farming on changes in type of family } \\
\hline & Joint & 128 & 103 \\
\hline & Separate/ Nuclear & 22 & 47 \\
\hline & Total & 150 & 150 \\
\hline \multirow{5}{*}{$\begin{array}{l}\text { Numbers of } \\
\text { family } \\
\text { members }\end{array}$} & \multicolumn{3}{|c|}{ Impact of poultry farming on changes in family members } \\
\hline & Two to four & 6 & 10 \\
\hline & Five to eight & 86 & 111 \\
\hline & More than eight & 58 & 29 \\
\hline & Total & 150 & 115 \\
\hline \multirow{4}{*}{$\begin{array}{l}\text { Family of bad } \\
\text { habit }\end{array}$} & \multicolumn{3}{|c|}{ Impact of poultry farming on changes in their bad habit } \\
\hline & Tobacco chewing & 53 & 35 \\
\hline & Bidi/ Cigarette & 74 & 55 \\
\hline & Total & 127 & 90 \\
\hline
\end{tabular}


Table.3 Additional income through poultry farming

\begin{tabular}{|c|l|c|}
\hline S. No & Item & No/Income (Rs.) \\
\hline 1 & Total egg produced per year & 161 \\
\hline 2 & Own use & 58 \\
\hline 3 & Sold in market & 103 \\
\hline 4 & Rate per egg & 4 \\
\hline 5 & Average existing birds & 7 \\
\hline & Total income (Rs.) & $\mathbf{2 8 8 4}$ \\
\hline
\end{tabular}

Table.4 Impact of poultry farming on change in their life style $(n=115)$

\begin{tabular}{|c|l|c|c|}
\hline S. No. & \multicolumn{1}{|c|}{ Parameters } & Number & Percent \\
\hline 1 & Food quality & 115 & 100.00 \\
\hline 2 & Clothes & 83 & 72.17 \\
\hline 3 & Housing & 15 & 13.04 \\
\hline 4 & Farm implements & 56 & 48.70 \\
\hline 5 & Farm expenses & 112 & 97.39 \\
\hline 6 & Children education & 113 & 98.26 \\
\hline 7 & Vehicle & 15 & 13.04 \\
\hline
\end{tabular}

The entertainment facilities were increased due to poultry farming and data depicted in Table 2 shows that the number of radio, TV, CD player and DVD players increased in number $23(20.00 \%), 9$ (7.83\%), $3(2.61 \%)$ and $1(0.87 \%)$, respectively due to poultry farming. These results are similar with Dhavan (2008) that sudden requirements like medical emergencies, celebrations, gifting etc. were taken care of using this extra income. Backyard poultry was used as a savings account which could be used as and when required.

The farmers were grouped according to their annual income during the survey and after technological interventions (Table 2). At the time of base line survey it was observed that the annual income of 39 (26\%) farmers were in the group of less than 8000, $102(68 \%)$ farmers were between 8000 to 15000 , while the remaining $9(6 \%)$ farmers were above 15000 (Table 2). After three years of technology interventions it was determined that the annual income of the farmers was gradually increased. The average annual income of the farmers was above the 8000 i.e. no farmers lies in the category of less than 8000. The youth farmers generated more income from the poultry farming than old. It was concluded that poultry farming is the best activities for sustainable livelihood. These results are agreement with Dhavan (2008) that increase in net income per household is Rs. $2280 /$ - i.e. $290 \%$ rate of return on investment with the poorest having highest net profit margin.

The number of nuclear families increased from $14.67 \%$ to $33.33 \%$ whereas the number of farmer family members decreased (Table 2). Majority of the farmers quit their bad habits viz. addiction to tobacco $(15.65 \%)$ and smoking (16.52\%).

Table 3 shows additional income produced through poultry farming. The increased income was utilized hugely by the farmers in improving their nutritional status and education for the next generation. Also some 
income was diverted towards betterment of their living standards and farm mechanization.

These results are agreement with Iannotti et al., (2009) that $33 \%$ and $30 \%$ of the additional income from poultry rearing was used on education and food respectively. Only $14 \%$ was used on clothes and none was used on housing (Table 4).

Poultry rearing is one of the best solutions for increasing the income of tribal farmers for sustainable livelihood. The tribal farmers can also fulfill their - requirement of the basic amenities. It is also observed that there is need to develop low cost housing techniques for poultry rearing to control the attack of the wild animals.

\section{References}

Alabi RA, Esobhawan $\mathrm{AO}$ and Aruna MB (2006). Econometric determination of contribution of family poultry to women's income in Niger Delta, Nigeria. Journal of Central European Agriculture, 7(2): 753-760.

Birol E, Marfo DA, Ayele G, Bonsu AM, Ndirangu L, Okpukpara B, Roy D and Yakhshilikov Y (2010). Investigating the role of poultry in livelihoods and the impact of avian flu on livelihoods outcomes in Africa. IFPRI Discussion Paper 01011, 1-40.

Callens K and Phiri EC (1998). Household food security and nutrition in the Lauapula Valley, Zambia. In: Food, Nutrition and Agriculture Alimentation Report. Food and Agriculture Organization (FAO), Rome, Italy.

Chitukuro HR and Foster HA (1997). 'Methodologies for enabling women to improve poultry productivity through better husbandry and disease control'. In, Sonaiya E.B. (eds). Sustainable rural poultry production in Africa. Proceedings of an International Workshop held on June 13-16, 1995 at the International Livestock Research Institute, Addis Ababa, Ethiopia, pp.108-111.

Dhavan M (2008). Small-scale poultry farming and poverty reduction in South Asia. South- Asia Pro- Poor Livestock Policy Programm e-SA PPLPP, New Delhi.

Epprecht M, Vinh LV, Otte J and RolandHolst D (2007). Poultry and poverty In Vietnam. HPAI Research Brief, No. 1.

FAO (2002). Improved animal health for poverty reduction and sustainable livelihoods. Animal Production and Health Paper, 153. Food and Agricultural Organisations of the United Nations, Rome, Italy www.fao.org/3/a/3542e.pdf

FAO (2014). Food Outlook. Food and Agricultural Organisations of the United Nations. Rome, Italy http://www.fao. org/3/a-i4136e.pdf

Guèye EF (2000). The role of family poultry in poverty alleviation, food security and the promotion of gender equality in rural Africa. Outlook on Agriculture, 29: 129-136.

Holst DR, Epprecht M and Otte J (2007). External shocks, producer risk, and adjustment in smallholder livestock production: The case of HPAI in Viet Nam. Pro-Poor Livestock Policy Initiative - A Living from Livestock, Research Report.

Iannotti L, Barron M and Roy D (2008). Animal source food consumption and nutrition among young children in Indonesia: Preliminary analysis for assessing the impact of HPAI on nutrition. DFID Pro-poor HPAI Risk Reduction Strategies Project Research Report.

Iannotti L, Cunningham $\mathrm{K}$ and Ruel $\mathrm{M}$ 
(2009). Improving diet quality and micronutrient nutrition. IFPRI Discussion Paper, 00928.

Islam R, Kalita N and Nath, P (2014). Comparative performance of Vanaraja and Indigenous chicken under backyard system of rearing. Journal of Poultry Science and Technology, 2(1): 22-25.

LID (1999). Livestock in poverty focused development. Livestock in Development, Crewkerne, UK:

Obi TU, Olubukola OA and Maina GA (2008). Pro- poor HPAI risk reduction strategies in Nigeria: Background Paper. DFID Pro-poor HPAI Risk Reduction Strategies Project, Africa/Indonesia Region Report No. 5

Quinn V, Chiligo M and Gittinger JR (1990). Malnutrition, household income and food security in rural Malawi. Health Policy and Planning, 5(2): 139-148.

Roland-Holst D, Epprecht $\mathrm{M}$ and Otte J (2007). External shocks, producer risk, and adjustment in smallholder livestock production: The case of HPAI in Viet Nam: Research Report. Pro-Poor Livestock Policy Initiative A Living from Livestock.

Rosenzweig M and Binswanger H (1993). Wealth, weather risk, and the composition and profitability of agricultural investment. Economic Journal, 103(1): 56-78.

Smucker, Thomas A and Ben Wisner (2008). Changing household responses to drought in Tharaka, Kenya: vulnerability, persistence and challenge. Journal Compilation at Overseas Development Institute. Blackwell Publishing.

Sonaiya EB (2007). Family Poultry, food security and the impact of HPAI. World's Poultry Science Journal, 63 (1): 132-138.

Sonaiya EB, Branckaert RD and Gueye EF (1999). Research and development options for family poultry. ${ }^{s t}$ INFPD/FAO Electronic Conference on Family Poultry, 7 December 1998 - 5 March 1999.

Talukder A, Haselow NJ, Osei AK, Villate E, Reario D, Kroeun $\mathrm{H}$, SokHoing L, Uddin A, Dhunge $S$ and Quinn V (2010). Homestead food production model contributes to improved household food security and nutrition status of young children and women in poor Populations. Field Actions Science Reports.

\section{How to cite this article:}

Singh, D.V., Anupam Mishra, S.R.K. Singh and Tushar Athare. 2017. Impact of Backyard Poultry Rearing on Living Standard of Tribal Community in Kandhamal District of Odisha, India. Int.J.Curr.Microbiol.App.Sci. 6(12): 3908-3914. doi: https://doi.org/10.20546/ijcmas.2017.612.451 